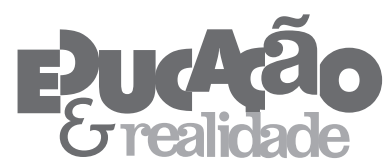

\title{
A Palavra e as Condições da Educação Escolar
}

Leandro de Lajonquière ${ }^{\prime}$

'Universidade de São Paulo (USP), São Paulo/SP - Brasil

RESUMO - A Palavra e as Condições da Educação Escolar. Estudos recentes sobre gestão e resultados escolares apontam a presença do, assim chamado, efeito-professor como um fator associado ao desempenho dos alunos. Desenvolve-se neste texto a premissa de que esses estudos acabam, paradoxalmente, demonstrando a pertinência da reflexão psicanalítica, que aponta para o estatuto da palavra mestre no interior de uma tradição filial professoral como condição necessária à educação escolar.

Palavras-chave: Palavra Professoral. Psicanálise e Educação. Freud e a Educação. Desejo e Educação. Avaliação Escolar.

ABSTRACT - Speech and the Conditions of Schooling. Recent studies on school management and results have pointed to the relevance of the socalled 'teacher effect' as a factor linked to the performance of pupils. The premise developed in this article is that such studies end up paradoxically demonstrating the relevance of the psychoanalytic reflection, which stresses the status of the teacher's speech within a filial teaching tradition as a necessary condition in school education.

Keywords: Teacher's Speech. Psychoanalysis and Education. Freud and Education. Desire and Education. School Assessment.

Educação \& Realidade, Porto Alegre, v. 38, n. 2, p. 455-469, abr./jun. 2013. 
A Palavra e as Condições da Educação Escolar

\section{A Palavra e as Condições da Educação ${ }^{1}$}

A pergunta pelas condições da educação não cessa de não se formular. Por um lado, insistimos em nos debruçar sobre ela e, por outro, dela também nada queremos saber. Paradoxo que o discurso psicopedagógico hegemônico tenta precisamente liquidar, formatar, e assim se constituir como campo científico. As condições da educação, ora familiar, ora escolar, são reduzidas a uma série de variáveis ou positividades atitudinais: faça-se isso, faça-se aquilo outro para obterem-se tais ou tais resultados dos alunos, dos filhos, em suma, das crianças. A pedagogia desconhece assim o assinalamento da psicanalista Françoise Dolto ${ }^{2}$ que quando pequena dizia querer ser quando grande médica da educação: "[...] não se trata de mudarmos nossos hábitos, mas a nossa atitude interior” (1994, p. 134).

No entanto, nestes últimos tempos, em particular no interior do campo pedagógico, tem surgido, conforme revelam Scartezini e Viana (2010), uma forma singular de se avaliar a qualidade do rendimento escolar. Tratar-se-ia de identificar fatores associados aos resultados dos alunos auferidos nas avaliações oficiais, ou seja, fatores cuja sutil composição também intervém no efeito final. Assim, Soares (2003, p.121) chega a afirmar, por exemplo, que “[...] as características do professor e do ambiente em sala de aula afetam decididamente o rendimento dos alunos". Nessa mesma direção, Gomes (2005), na esteira de pioneiros norte-americanos, fala em termos de professores eficazes cujos atributos escapariam aos critérios burocráticos de recompensas em suas carreiras. Por outro lado, pesquisadores como Klein e Fontanive (2010) propõem como eixo de investigação a entrada nas salas de aula para se abrir a caixa preta do lado emocional dos professores que obtêm bons resultados com seus alunos, graças à utilização de equipamentos audiovisuais. Esse diferencial, não dependente do nível intelectual, dos assim considerados professores eficazes, poderia por sua vez ser ensinado a outros no contexto da formação continuada.

Dessa forma, pareceria que se delineia no horizonte dos dias atuais, a ideia de que a chave do sucesso educativo escolar seria uma espécie de fator de impacto professoral de natureza totalmente independente de qualquer outra condição, capaz de infligir uma diferença no conjunto das variáveis comumente estudadas e que intervêm no rendimento escolar, bem como suscetível de ser replicado em série.

É de fato curioso o surgimento desta nova forma de se colocar a questão do sucesso escolar. Ela descortina uma nova perspectiva. Não se trataria tanto dos saberes livrescos detidos pelo professor, como classicamente pensado, mas de um algo emocional capaz de impactar a capacidade de atenção das crianças em sala de aula. Esta mudança de visão parece ser salutar, após décadas de pragmatismo utilitarista no campo da pedagogia. Porém, como pretendo desenvolver à continuação, creio que assim colocada a questão, trata-se de uma empresa que, 
embora assinale timidamente para a implicação da palavra na educação, em última instância, nada quer saber da fragilidade artificial inerente ao laço educativo como umas das formas de nos havermos com a alteridade.

É consensual no campo da pedagogia afirmar que a educação implica na transmissão às crianças e aos jovens de um conjunto parcial de conhecimentos que as gerações anteriores souberam acumular. Porém, as divergências começam na hora de elucidarmos até que ponto esses seres pequenos, chegados ao mundo após os adultos, quando aprendem algo não só adquirem certo domínio sobre algum dos mundos possíveis - aqueles das letras, da natureza, ou das virtudes humanas, dentre outros - mas também são marcados pelo mesmíssimo apre(e)nder ${ }^{3}$ no próprio coração da vida. Eis aqui, precisamente, a questão chave para entendermos como a educação, seja familiar, seja escolar, releva então da função e campo da palavra e da linguagem ${ }^{4}$ como costumamos afirmar nos estudos em psicanálise e educação.

$\mathrm{O}$ fato de alguns pesquisadores, dedicados à avaliação e à gestão escolar, após terem se dedicado anos a fio a entrecruzar variáveis de todo tipo, com vistas a identificar o $x$ da questão na aprendizagem escolar, falarem atualmente em termos de um algo emocional do lado do professor, suscetível de produzir bons resultados quando tudo indicaria estatisticamente o contrário - o fracasso da criança -, parece avançar na direção assinalada pela psicanálise na educação. Parece, mas não é.

O assinalamento feito por esses colegas não consegue infelizmente ultrapassar as limitações do paradigma empírico-positivo de origem e, portanto, a sua contribuição - a meu ver - não aponta para a subversão do status quo na formação de professores no Brasil.

Em certo sentido, poder-se-ia dizer que os pesquisadores, lembrados no estudo de Scartezini e Viana (2010), seguem as pegadas deixadas por Albert Camus e Sigmund Freud quando de lembranças da escola se trata, mas eles acabam, em última instância, passando ao lado da questão chave, qual seja, a implicação da palavra no ato educativo.

Albert Camus, após receber a notificação da outorga do Prêmio Nobel de Literatura de 1957, escrevera uma carta, datada em 19/11/1957, àquele que tinha sido seu professor primário na Argélia francesa, já passada a primeira grande guerra mundial:

Caro Monsieur Germain [...] Deixei passar um pouco o frenesi destes últimos dias para, assim, endereçar-me de coração ao Senhor. Acabo de receber uma grande honra que eu nem busquei nem solicitei. Porém, quando recebi a notícia a primeira pessoa que lembrei, após minha mãe, foi o Senhor. Sem o Senhor, sem essa mão afetuosa que o Senhor estendeu à criança pobre que eu era, sem o seu ensino e sem o seu exemplo, nada de tudo isto teria acontecido. Não exagerarei a sorte desta honraria. Porém, trata-se 
A Palavra e as Condições da Educação Escolar

de uma oportunidade para dizer o quê o Senhor não só foi senão também o quêainda é para mim, bem como para lhe assegurar que os seus esforços, o seu trabalho e a generosidade com a qual o Senhor se empenhava estão ainda presentes num daqueles pequenos escolares, que apesar da idade, não cessou de lhe ser grato. Abraço fortemente $o$ Senhor ${ }^{5}$ (tradução livre).

Por outro lado, Sigmund Freud, em 1914, por ocasião de proferir um discurso de saudação pelo jubileu do $50^{\circ}$ aniversário do liceu que frequentara, quando jovem, em Viena, afirmou:

Minha emoção ao encontrar meu velho mestre-escola adverte-me de que, antes de tudo, devo admitir uma coisa: é difícil dizer se o que exerceu mais influência sobre nós e teve importância maior foi a nossa preocupação pelas ciências que nos eram ensinadas, ou pela personalidade de nossos mestres. É verdade, no mínimo, que esta segunda preocupação constituía uma corrente oculta e constante em todos nós e, para muitos, os caminhos das ciências passavam apenas através de nossos professores. Alguns se detiveram a meio caminho dessa estrada e para uns poucos - porque não admitir outros tantos? - ela foi por causa disso definitivamente bloqueada. Nós os cortejávamos ou lhes virávamos as costas; imaginávamos neles simpatias e antipatias que provavelmente não existiam; estudávamos seus caracteres e sobre estes formávamos ou deformávamos os nossos. Eles provocavam nossa mais enérgica oposição e forçavam-nos a uma submissão completa; bisbilhotávamos suas pequenas fraquezas e orgulhávamo-nos de sua excelência, seu conhecimento e sua justi$c a$. No fundo, sentíamos grande afeição por eles, se nos davam algum fundamento para ela, embora não possa dizer quantos se davam conta disso. Mas não se pode negar que nossa posição em relação a eles era notável, uma posição que bem pode ter tido suas inconveniências para os interessados (Freud, 1914, p. 286, grifo meu).

O título com o qual essa alocução foi incluída nas Obras Completas em língua portuguesa, editadas no Rio de Janeiro, é sumamente ilustrativo: Algumas Reflexões sobre a Psicologia do Escolar. Em outras palavras, Freud elucida aquilo que se processa nas cabecinhas dos jovens quando (em)prestam atenção a velhos implicados no professar. Há algo na personalidade do velho mestre-escola que professa, que influencia, toca, impacta os jovens candidatos a e(a)nunciar, por sua vez, as verdades das ciências. Isso em pauta, que faz às vezes de embreagem da mudança de posição existencial de discípulo a mestre no interior do campo da palavra e da linguagem, não é relativo à clareza e à distinção com as quais as epistémes são ensinadas. Isso está precisamente ligado aos curiosos e pequenos detalhes da personalidade daqueles dedicados ao exercício de uma mestria enunciativa. A mestria enunciativa deve ser pensada em outro registro, diferente daquele do imaginário contro- 
le autoral do discurso, pois, caso contrário, não haveria excentricidades na personalidade do mestre. Em suma, d'isso ${ }^{6}$ do qual se trata no laço educativo e do qual Freud nos fala é da castração, do desejo, isto é do inconsciente.

As declarações de Albert Camus vão nessa mesma direção. Além do ensino em si mesmo, a criança aprendiz das letras é tocada pelo exemplo do mestre, pelo afeto, pela generosidade e pelo trabalho empenhado. E tudo isso não é sem inconveniências, retomando o comentário freudiano. Mais ainda, os efeitos do impacto da geração mais velha não cessam de não se escrever ${ }^{7}$ na obra do premiado escritor, outrora jovem aprendiz, assinalando, assim, a atemporalidade do saber inconsciente.

No entanto, os pesquisadores interessados atualmente na eficácia professoral, devido às limitações paradigmáticas, não conseguem tirar as devidas consequências d'isso, que eles intuem, à sua maneira, estar operando em sala de aula, para além das variáveis classicamente auferidas. Bem poder-se-ia dizer - parafraseando o título de uma obra de Gerard Pommier ${ }^{8}$ - que neste ponto essas pesquisas sobre avaliação e gestão escolar acabam demonstrando de fato a pertinência de nossos estudos em psicanálise e educação.

Neste contexto, permito-me recuperar sinteticamente à continuação uma tese já exposta por mim há quase uma década e meia ${ }^{9}$ que tenta elucidar, graças à psicanálise, isso que está em pauta no laço educativo, em conformidade com as lembranças escolares de Albert Camus e Sigmund Freud.

Quando uma criança adquire o domínio de uma série de conhecimentos, acaba então se parecendo um pouco com o adulto - mestre de ocasião. Mais ainda, quando aprende - apreende para si aquilo que antes era apenas possuído por delegação pelo adulto - acaba sujeitada, mesmo que seja por um fio, a toda uma tradição. O conhecimento transmitido é o embrulho de uma marca de pertinência a uma tradição que carrega em si mesma uma dose de existência, uma cota de saber fazer com a vida, ou seja, um savoir vivre ou saber existencial que não se reduz ao conhecimento sobre nenhum dos mundos possíveis - aqueles das letras, dos números, etc.

Assim sendo, quando os pais ensinam seu filho quem ele é, até certo ponto, para os outros (a começar por eles mesmos), colocando-lhe um nome que vetoriza certos ideais, como também quando uma professora ensina a Pedrinho os números, instala-se uma divida. Tanto um quanto o outro passam a dever algo pela sua existência. Como sabemos, uma coisa é dever uma quantia $x$ de dinheiro para um amigo e outra, muito diferente, é o preço da amizade. Com os nomes e os números ocorre algo parecido: todo respeito será pouco para saldar a dívida pela existência ou, em outras palavras, o sentido que a vida pode ter acabado de ganhar. No valor incalculável da mesma está embutida uma infindável pergunta: o Outro, o que quer de mim? O nome próprio e os números aprendidos tiram um bocado da estupidez da vida empírica, mas é o ato

Educação \& Realidade, Porto Alegre, v. 38, n. 2, p. 455-469, abr./jun. 2013. 459 Disponível em: <http://www.ufrgs.br/edu_realidade> 
A Palavra e as Condições da Educação Escolar

de nominação e o de ensinar em si quem instalam ou marcam a fogo essa pergunta nas nossas vidas. O chamado desejoé precisamente o eco da impossibilidade de vir a dar-lhe resposta conclusiva.

Sobre o desejo não há conhecimento algum, mas, saber. O saber sobre o desejo é certo saber cujo grande valor reside na sua fútil inutilidade, uma vez que o mundo sobre o qual versa é aquele do impossível. Esse saber, ao contrário dos conhecimentos, não se estrutura em sistemas cada vez mais equilibrados conforme algum ponto virtual de referência histórico-mundana. O saber sobre o desejo apenas se articula nas vicissitudes da existência mundana, pois sua natureza é da ordem de um paradoxo, qual seja: querer saber sobre o desejo e não querer saber que é impossível saber que não há saber sobre o desejo. Assim, o saber sobre o desejo é, em última instância, o saber da mesmíssima impossibilidade de se saber sobre o desejo. Ele é o saber não-sabido do desejo. Trata-se de um saber irreflexivo, de um saber que não se sabe e, portanto, fala-se em termos do saber recalcado e do saber inconsciente.

A dívida de toda criança para com o adulto mestre ocasional é de natureza estritamente simbólica. Por um lado, a transmissão - releva da função e campo da palavra e da linguagem e não do registro das coisas. Por outro, é também simbólica no sentido em que a criança nada deve no real, pois o transmitido não pertencia de fato ao adulto. Este doa por delegação ou direito, aquilo que não deixa de ser sempre propriedade de uma tradição. Ele se autoriza, devidamente, invocando a potestade graciosa própria da tradição dos adultos que obraram com mestria. Mais ainda, essa invocação - e, portanto, o reconhecimento da dívida nela embutida - outorga caráter verdadeiramente simbólico ao ensinado. $\mathrm{O}$ mostrado no ensino, em lugar de ser um simples índice do amor magistral, é assim um signo sui generis - um significante - tanto da dívida do adulto pelo empréstimo parcial do qual goza, quanto do desejo em causa no ato educativo

Na educação, a transmissão do saber recalcado e da dívida simbólica efetiva-se sob a forma do (que é) ideal. Em todo ato educativo há embutido uma cota de dever ser ideal. Assim, quando alguém ensina os números está dizendo ao aprendiz que chegar a conhecer o resultado de $2+2$ é tanto uma forma de vir a ser um pouco matemático como aquele que ensina quanto o dever de qualquer um que preze ser um crente em números. Mais ainda, o nome que os pais colocam ao filho faz também alusão a uma série de ideais ou conjunto quase sempre heteróclito de mandatos existenciais que finca suas raízes na realidade fantasmática parental.

Os ideais são de ordem tanto simbólica quanto imaginária. O ideal é imaginário quando não assume a forma de um dever ser paradoxalmente sempre retrospectivo, mas aquela de um mandato que se autoesvazia de futuro no presente mesmo de sua formulação. O ideal imaginário é simplesmente um mandato feito de puro estofo especular, isto é, trata-se do pedido de complementação narcísica daquele mesmo que 
o enuncia. Assim o ideal, em vez de levar embutido um dever ser - uma dívida para com o passado das matemáticas ou da família-, encerra em si mesmo o dever de ser a metade que ao mandante lhe falta para ser Um indiviso ou, lembrando Freud, para vir a ser o Ego-Ideal.

Os Ideais do Ego, enquanto simbólicos, não tem por missão formatar a falta do/no sujeito. Quando o ideal é simbólico, o saber veiculado é um saber-não-sabido, pois, embora no horizonte se recorte uma razão de ser, o sujeito nunca virá a saber certamente sobre a diferença entre ser e dever ser o ideal, no seio da qual aninha-se o desejo. Ao contrário, o ideal imaginário veicula um saber mais parecido com a certeza; então, aquele que recebe a injunção de ser, agora, não só sabe o que lhe estão pedindo senão também como é que se faz para ser. À vista disso, esse saber sobre o desejo passa a ser um saber de fato sabido e, portanto, o veiculado acaba se revelando não um desejo, mas um voto de gozo.

Dessa forma, na educação, seja familiar, seja escolar, além dos conhecimentos transmitidos, há em operação um saber que, ao contrário, perpassa em negativo no seio do ato. Trata-se do saber da impossibilidade de se ensinar a totalidade da epistéme, da impossibilidade dos ideais, bem como do mesmíssimo desejo que, embora transmitido por amostra, não é daquele que dele dá testemunho, mas do Outro conforme a psicanálise.

Em suma, toda educação que se preze implica na transmissão, no campo da palavra e da linguagem, dos conhecimentos mais variados, bem como também do desejo inconsciente que nos humaniza.

$\mathrm{O}$ adulto que ensina, o faz porque, alguma vez, deve ter aprendido aquilo que tenta transmitir. Aquilo que ensina, embora seja dele, pois o aprendeu, não lhe pertence. O apre(e)ndido é sempre emprestado de alguma tradição. Assim, aquele que aprende de fato contrai automaticamente uma dívida que, embora acredite às vezes tê-la com seu mestre ocasional de quem teria supostamente apreendido o ensinado, está em última instância assentada no campo da palavra e da linguagem.

Dessa forma, como todo mestre foi alguma vez aprendiz, ele não passa de um devedor. Pois bem, por que o mestre ensina? Aquilo que ensina é uma amostra de que e do que deve. Em outras palavras, aquilo que o mestre mostra, para assim educar o aprendiz de plantão, é a prova de seu dever. O mestre ensina porque afinal de contas esse é seu dever. Ensinar é de fato sua própria e justa sina.

O mestre não pode não ensinar o que aprendeu, uma vez que o apre(e)ndido leva consigo um pecado de origem, qual seja, o de uma dívida que, embora reconhecida, não pode de fato ser saldada. Essa dívida é simbólica, pois aquele que ensina não faz mais que emprestar da tradição. Reconhecer uma dívida simbólica é reconhecer o estofo simbólico da dívida em questão, é aceitar inconscientemente a castração. Reconhecer a dívida significa que o aprendiz, por um lado, declara ter tomado emprestado e, por outro, aceita que o emprestado acarreta uma eleição. Por exemplo, aprender os números me obriga a fazer contas

Educação \& Realidade, Porto Alegre, v. 38, n. 2, p. 455-469, abr./jun. 2013. 461 Disponível em: <http://www.ufrgs.br/edu_realidade> 
A Palavra e as Condições da Educação Escolar

conforme uma legalidade e não outra, como, aliás, fazem-no todos os sujeitos que são um pouco matemáticos. Mas também, tê-los aprendido me obriga a fazer uma escolha a respeito dos saberes ou ideais veiculados na educação, do tipo para ser matemático tem que dedicar-se o tempo todo aos números. Entretanto, uma coisa são as obrigações contidas nos ideais e outra diferente é a obrigação de reconhecer o fato de que o mesmíssimo ideal está em causa no ato. Todo ideal manda escolher entre ele e outro. Logo, a escolha embutida nele se revela, em última instância, isomórfica àquela de ter que optar entre a bolsa ou a vida. Semelhante escolha não é sem consequências. Assim sendo, reconhecer a dívida é aceitar a vida que só o símbolo pode dar: uma vida à qual falta sempre um pouco mais para ser ideal. O reconhecimento da irredutibilidade dessa diferença obriga o sujeito a sempre tentar mais uma vez um ato que honre o ideal. Em outras palavras, a lembrança dessa diferença condena o sujeito a não renunciar a um ato, cujo único fundamento não é outro que a sujeição à dívida simbólica para com o injustificável dever de arriscar.

O sujeito, lembrando-se e lembrando outros do dever-ser, na imperfeição de cada ato, mantém vivo o estofo ideal próprio do simbólico. Se porventura ele não lembrar o/do dever, o ideal deixaria, simplesmente, de ser tal, bem como o próprio sujeito perderia seu rumo existencial.

O aprendiz, ao contrário do mestre, que atua por dever, é movido na sua tarefa por amor ou, lembrando o neologismo lacaniano, por amódio $^{10}$. Quando o mestre oferta seu ensino, instala no seu interlocutor, o desejo de saber mais sobre aquilo que cai no ato educativo, bem como alimenta o amor do aprendiz por aquele que lhe aparece como sabendo d'isso que faz falta nele.

$\mathrm{O}$ ato de ensinar instaura retrospectivamente um tempo no qual o sujeito estava desprovido de saber algum e, portanto, de agora em diante quer saber sobre aquilo que passou a fazer falta. Isso que quer saber - o saber sobre o desejo -, o aprendiz o supõe no mestre, ao ponto tal, de pretender usufruir um pouco dele, ofertando, em troca, seu amor, bem como demandando àquele o restante para, assim, ambos fazerem Um, a qual nada falte. Aquilo que o aprendiz deseja é impossível, pois, por um lado, se porventura o fosse, então, acabaria a própria razão que move sua existência, ou seja, o desejo. E, por outro, o mestre não pode, de fato, entregar aquilo que não possui no real. Entretanto, o mestre sabedor do impasse que aprisiona ambos - doa simbolicamente aquilo que, embora não tenha, sabe onde tomá-lo emprestado - da tradição. É verdade que dessa maneira não entrega o pedido, mas cumpre com seu dever de sustentar as condições da educação.

Por exemplo, aquele mestre, um pouco matemático, na medida em que ensina, inocula o germe da razão que impera no mundo dos números, mostra certo saber, bem como leva o aprendiz a demandar seu amor, na exata proporção daquilo que não pode ser ensinado. Assim sendo, seria uma tolice da sua parte pretender entregar o pedido, pois, 
em primeiro lugar, a satisfação do aprendiz se esfuma com a mesma rapidez que uma miragem no deserto; em segundo lugar, uma vez desfeito o feitiço e dependendo do tamanho do ódio desencadeado, o iludido passa tanto a recusar a educação quanto a infernizar a vida do mestre; e, em último lugar, estaria renunciando a seu dever de honrar a dívida contraída, via a categoria dos matemáticos, com o mundo dos números. Nesse sentido, resta ao mestre ocupar sem vergonha, mas com sabedoria, esse lugar impossível. Fazendo semblante que sabe e que algum dia seu saber será do aprendiz, dá tempo ao tempo. O aprendiz apre(e)nde e, antes que seja capaz de perceber, estará a tal ponto atolado em dívidas, para com os números, que não só esquece de cobrar do mestre quanto passa a lembrar seu ensino em cada conta bem feita.

Em suma, enquanto o mestre entra na jogada por dever, o aprendiz o faz por amor. Este passa a querer saber e, logo mais, sem por isso renunciar totalmente à lembrança de seu primeiro encanto, ocupa seu tempo cotidiano tentando conhecer para si e para outros toda a razão - dos números, das letras, etc. - que, alguma vez, o invadiu em estado germinal. Mais ainda, embora o aprendiz de outrora passe a ocupar, por sua vez, o lugar sempre vacante de velho mestre em assuntos mundanos, a memória inconsciente desse encanto seguirá sendo lembrada com maior ou menor pompa e cerimônia.

Chegados a este ponto, não devemos nos surpreender que após terem cruzado fatores e fatores, as investigações sobre os bons resultados escolares assinalem para a existência de um fator que, embora entre na contabilidade, a ela também paradoxalmente escapa, não podendo ser contado, significado. É d'isso que causa o ato educativo do qual Camus e Freud deram testemunho quando se lembraram de seus mestres. Eis isso que na psicanálise chama-se desejo inconsciente, e que eu, parafraseando Lacan, a propósito da função do analista, vou-me permitir nomear no contexto deste desenvolvimento de desejo de mestre.

\section{$* * * * * * *$}

A educação de uma criança, assim como também a formação de professores, releva sempre da mesma questão, em pauta desde que o homem é homem e, portanto, desde que a uma geração lhe siga outra objeto de educação e formação: todo professar entranha o endereçamento da palavra de um mestre a um discípulo. Tanto uma quanto a outra, são processos abertos de passagem de uma posição a outra no campo da palavra e da linguagem, um giro trans/formador da posição de discípulo à de mestre no discurso. Entre ambos os lugares no discurso medeia uma alteridade de impossível formatação. Por que insisto em falar em mestre e discípulo quando da educação e da formação se trata? Vejamos.

Todo adulto na posição de professor deve professar - confessar, ensinar, preconizar, apregoar, propagar, fazer votos, prometer, ter afeição, amizade, conforme reza o dicionário Aurélio (Ferreira, 1986) da língua portuguesa - e, para tanto, deve se lançar à fala, à enunciação, à palavra. Em suma, um professor tanto enuncia sentenças quanto pro-

Educação \& Realidade, Porto Alegre, v. 38, n. 2, p. 455-469, abr./jun. 2013. 463 
A Palavra e as Condições da Educação Escolar

fessa verdades que ele fez também suas ${ }^{11}$ quando da sua formação. No professar, alguém fala enquanto outros prestam atenção emprestando seus ouvidos. O primeiro é mestre falante e os segundos são discípulos mudos. O mestre é sujeito de um (e num) discurso, enquanto todo discípulo é aquele que, num primeiro momento, é, em certo sentido, infans - privado de palavra nos assuntos professados pelo mestre de plantão.

A formação de professores é, ou deveria ser, uma formação de mestres. O debate em torno de suas condições de possibilidade deveria sempre considerar que é disso que se trata, isto é, das condições de discípulos, em princípio infans, virarem mestres de e em algo discursivo - as matemáticas, a mitologia, a gramática portuguesa, etc. - para jovens orelhas alheias. Portanto, trata-se de um processo isomórfico à educação familiar e escolar de uma criança sob o império da palavra do adulto em posição educativa, numa posição de mestria ${ }^{12}$.

No entanto, nada disso se quer saber nos dias de hoje no campo da pedagogia e, em particular, nos debates em torno da formação profissional. Por que será?

Talvez, parte do esquecimento de que se trata de uma profissão de mestria, obedeça ao fato de que a língua portuguesa, ao menos a falada no Brasil, mantém em uso, no corriqueiro dia-a-dia, o termo mestre para aquele que dirige cerimônias, aquele que dirige operários da construção (mestre de obras) e para aquele que obtém um mestrado como dignidade universitária. De fato, no Brasil, criança ou jovem nenhum chama ainda de mestre ao professor de escola.

Entretanto, o francês e o espanhol mantêm em uso os termos maître-e o feminino maîtresse-bem como maestro - e o feminino maestra - quando se trata de todo e qualquer professor do primário. Mais ainda, não sem algumas curiosidades. Por exemplo, na língua francesa, maîtresse também significa amante, bem como mulher que exerce influência sobre um homem. Em espanhol, ao menos na Argentina, uma maestra é também chamada pelas crianças de señorita ${ }^{13}$, que, no imaginário infantil, é uma mulher que ainda não é casada, isto é, que não participaria, como se dizia antigamente, do comércio sexual e, portanto, que se manteria fora do alcance da castração e do desejo, uma mulher tomada, então, só no registro do amor impoluto - la señorita.

Temos, assim, que uma língua esquece o que as outras duas lembram, embora também não querendo saber às claras. Porém, há ainda outro detalhe. A língua falada no Brasil esquece mestre no intuito de impor professor, mas vê-se às voltas com o retorno do recaldo pela boca das crianças quando estas falam tia. É compreensível que a esquerda pedagógica tenha se revelado contra o uso do termo tia, mas temos de convir que não foi nem um general nem um tecnocrata liberal da educação que o inventou. De qual tia se trata? Essa tia está no lugar de uma mãe que não é mãe e, portanto, que não estaria marcada pela proibição do incesto. 
Então de que se trata? O saber das línguas que retorna pela boca das crianças indica que toda mestria entranha o recalque do sexual, isto é, do desejo. É do desejo e, portanto, da castração embutida na própria mestria que nada se quer saber, de forma particular na formação de professores.

O exercício da mestria entranha - paradoxalmente - o reconhecimento do desejo em causa no ato. Disse paradoxalmente, pois há uma tendência em se considerar que é mestre, ao contrário, aquele situado fora do alcance da castração. Porém, devemos distinguir o mestre dos impostores da mestria revestidos com todo tipo de ouropéis autoritários. Há discurso do mestre ${ }^{14}$, mas não propriamente mestre do discurso, embora bem se possa dizer que o mestre seja de fato a mesmíssima palavra. O exercício da mestria implica o reconhecimento da sujeição à palavra de um discurso e, portanto, todo mestre de carne e osso é paradoxalmente aquele personagem que dá testemunho da mesmíssima castração que o anima na profissão impossível da mestria.

A mestria e a castração compõem uma fita de Moebius. Com a paternidade acontece outro tanto. Corriqueiramente pensa-se que a paternidade dá lugar a uma linhagem para frente: alguém se diz pai perante uma criança - seu filho. Mas a paternidade se reflete no retrovisor. Alguém pode bancar o pai perante o filho, pode nomear outro como sendo o seu filho sempre e quando se reconheça filho de outro que o precedeu no discurso. O homem embora sempre seja filho de alguém, só terá um pai na medida em que o tenha assim reconhecido simbolicamente, que tenha feito sua a palavra dele, que tenha aceitado ser seu filho $^{15}$. Não há paternidade sem filiação e vice-versa e, portanto, sem a castração que impossibilita que os lugares sejam cheios e absolutos. É-se pai à medida que se é também filho. Não só no sentido que o hoje pai fora antes filho-criança e que, embora crescido, continua civilmente sendo filho de alguém. Trata-se, fundamentalmente, de que só no momento em que se reconhece filho é que pode de fato bancar o pai. Em suma, não há paternidade sem castração.

Se não há nem mestria nem paternidade sem castração, então, ambas só são possíveis no interior de uma filiação. Um pai só pode endereçar a sua palavra na sua condição de filho. A palavra endereçada ao pequeno testemunha a castração que anima a enunciação, isto é, o fato de que o pai em questão se reconhece filho de outro que, por sua vez, o era de outro e assim por diante. Então, todo pai fala do lugar da castração do predecessor e, portanto, da divida simbólica transmitida de geração em geração conforme desenvolvemos acima. Da mesma forma, o mestre só pode endereçar a sua palavra à condição de perlaborar ${ }^{16} 0$ fato de ser discípulo de outro, isto é, de ter sido infans com relação a uma palavra mestre. Portanto, a palavra do pai e a do professor só advém no interior de uma tradição filial à qual se tem acesso pagando o preço da castração e do reconhecimento do desejo. 
A Palavra e as Condições da Educação Escolar

Na formação de formadores não há como driblar o fato de que o candidato deve, primeiro, emprestar suas orelhas à invocação de uma palavra professoral, para após tomá-la por assalto para vir a se lançar, por sua vez, à aventura da e(a)nunciação ${ }^{17}$. A formação impõe um custo psíquico ou uma implicação subjetiva do candidato, além - é claro - do esforço e do tempo dedicados ao estudo da matéria.

Para poder professar o saber inconsciente de uma língua epistêmica qualquer - as matemáticas, o português, a história, etc. -, o candidato deve, primeiro, alienar-se nela, para só depois encontrar para si um lugar de fala no interior de uma tradição filial. A conquista desse lugar entranha o custo psíquico de ter que se haver com a palavra do mestre, com a mestria em si da palavra mesma. Essa conquista é formativa ou, se preferirmos, ela é o nó da mesmíssima profissionalização dos professores. Por sinal, é essa necessária implicação subjetiva, na perlaboração do fato de ter sido objeto de uma palavra professoral, que as atuais iniciativas de formação profissional on-line fantasiam poder contornar $^{18}$.

Em suma, não há fala professoral passível de impactar orelhas alheias sem tradição filial de mestres, e vice-versa. No entanto, é isto que as novas investigações sobre o dito efeito-professor ou fator de impacto não conseguem pensar. Trata-se nelas de mais uma competência pessoal, embora emocional e, talvez, até a mãe de todas as outras, factível de ser identificada pela observação e replicada graças a seu ensino.

Dessa forma, a questão que se coloca é até que ponto o Estado e os governos dão ou não sustentação à institucionalização de uma filiação professoral, no interior da qual uma palavra mestre terá chances de advir. Cada candidato deve conquistar psiquicamente o seu devido lugar de mestre. Essa prova se coloca no singular para cada um deles. Mas o Estado e os governos podem e devem criar condições políticas para que uma tradição ou filiação professoral possa advir no país. Só do interior dessa tradição, a fala de um professor terá chances de impactar as orelhas infantis além do caso a caso das contingências pessoais.

Nesse sentido, aqui a história assinala o caminho: a tradição professoral só vinga no terreno aberto pela instalação de uma carreira funcional de Estado no interior de um projeto político de Nação amarrado em torno da convicção de uma educação para todos ${ }^{19}$. Quando ela existe e a tradição professoral então se instala, a palavra do mestre não só impacta as jovens orelhas, senão que também mantém esse poder para além de certas contingências funestas mais ou menos transitórias na história, que bem poderiam reservar um destino funesto para uma ou outra criança. Foi o caso precisamente de Sigmund Freud, judeu pobre na Viena imperial, e de Albert Camus, pied-noir ${ }^{20}$ órfão e pobre na Argélia francesa.

A tradição filial, em cujo seio pode emergir uma palavra com poder de impactar, não é imutável e, portanto, bem pode acabar se desmanchando se o Estado insiste em descuidá-la ou simplesmente em 
atacar os fundamentos de seu poder. Infelizmente, a história dá também (maus) exemplos nessa direção. É o caso do governo neoliberal e reacionário de Saúl Menem na Argentina, que procedeu, nos anos noventa do século passado, à desmontagem do secular sistema de educação nacional, responsável pela escolarização massiva. Para além da questão do financiamento educativo, o que deve ser lembrado é que a desmontagem menemista golpeou aí onde sabia-se (inconscientemente) que se devia atacar: a tradição filial professoral. A arma usada foi o argumento oficial da falta de competências técnicas dos professores à luz das novas pesquisas psicopedagógicas.

Neste contexto, então, é possível inferirmos que a insistência em se formar professores no Brasil, na esteira do rumo assinalado pelo sempre renovado tecnopragmatismo pedagógico feito academia, desconsidera este dado essencial. Reiterando, assim, a vocação tecnicista da escolarização brasileira cujo viés reacionário foi já esclarecido magistralmente por Maria Helena Souza Patto (1990). Portanto, a subversão do status quo pedagógico nacional implica necessariamente uma política de estado capaz de instalar no imaginário social um lugar de fala para os professores perante as jovens orelhas. É nesse lugar de fala ou de enunciação no interior de uma tradição filial, a ser conquistado por cada um dos candidatos a educador profissional, que a emergência de uma palavra mestre é suscetível de advir e, assim, embaralhar as condições sempre frágeis de uma educação.

Recebido em 17 de outubro de 2012 Aprovado em 10 de abril de 2013

\section{Notas}

1 Texto redigido no contexto das atividades do projeto FAPESP 11/03897-6 junto ao CERSE-EA 965, France. Agradeço os avaliadores pelas observações e comentários.

2 A pequena Françoise sabia - assim como a Mafalda, do cartunista Quino, costumava o dizer do mundo - que a educação estava doente.

3 Jogo entre aprender e apreender, pois na aprendizagem se trata de tomar, de se apropriar de um conhecimento.

4 Referencia à operação conceitual realizada por Jacques Lacan no que tange a elucidar a direção e princípios do poder da cura analítica, apresentada no texto Fonction et champ de la parole et du langage en psychanalyse (1953). A versão brasileira desse texto utiliza o termo fala. No entanto, opto por usar neste, assim como em outros de meus textos em português, o termo palavra pelas ressonâncias que ele permite. Por exemplo, diz-se Te dou a palavra; assim como alguém pode cobrar de outro: Mas, você me deu a sua palavra!. Ou ainda, Eu tomei a palavra e então disse. Ao contrario, o termo fala escamoteia esses jogos possíveis que bem assinalam a implicação subjetiva na enunciação.

5 Lettre d'Albert Camus à Louis Germain, 19/11/1957. Centre Albert Camus, Aix en Provence (França). Disponível em: <http://www.citedulivre-aix.com/Typo3/

Educação \& Realidade, Porto Alegre, v. 38, n. 2, p. 455-469, abr./jun. 2013.

Disponível em: <http://www.ufrgs.br/edu_realidade> 
A Palavra e as Condições da Educação Escolar

fileadmin/documents/Expositions/centrecamus/exposuede57.htm>. Acesso em: 05 out. 2012.

$6 \mathrm{O}$ artigo demonstrativo isso é grafado em itálico com vistas a estabelecer um jogo de palavras com o substantivo o Isso, utilizado pela psicanálise lacaniana de língua portuguesa para significar o saber inconsciente ou o Id.

7 Referência à afirmação lacaniana sobre o saber inconsciente.

8 Comment les neurosciences démontrent la psychanalyse, Paris : Flammarion, 2004.

9 “Dos erros e em especial daquele de renunciar à educação". Estilos da Clinica (USP), v. 2, n. 2, p. 27-43, 1997. Essas ideias foram posteriormente desenvolvidas em Infância e ilusão (psico)pedagógica (1999).

10 Condensação dos termos amor e ódio.

11 Pois antes essas verdades eram de outros - da categoria daqueles que já as professavam.

12 Cf. "A mestria da palavra e a formação de professores". Educação \& Realidade, Porto Alegre, v. 36, n. 3, p. 849-865, 2011.

13 Hoje em dia as crianças argentinas têm uma tendência a chamar a senhorita de simplesmente senho. O que não é sempre aceito por todas as professoras de escola primária. Os alunos do nível secundário usam os termos professor, professora ou senhor, senhora.

14 Alusão aos quatro discursos lacanianos: discurso do amo, da histérica, do analista e discurso universitário.

15 Não são todos os pais que em certas circunstâncias se endereçam a seu filho lembrando na oportunidade dos dizeres do avô.

16 Termo freudiano que indica o estofo do trabalho psíquico inerente à elaboração.

17 Grafia condensada de enunciar e anunciar que faz alusão ao professar.

18 Cf. "A mestria da palavra e a formação de professores". Educação \& Realidade, Porto Alegre, v. 36, n. 3, p. 849-865, 2011.

19 Cf. Figuras do Infantil (2010).

20 Literalmente pé-preto, forma familiar de se chamar os franceses habitantes da Argélia colonial.

\section{Referências}

CAMUS, Albert. Lettre d'Albert Camus à Louis Germain, 19/11/1957. Centre Albert Camus, Aix en Provence (França). Disponível em: <http://www.citedulivreaix.com/Typo3/fileadmin/documents/Expositions/centrecamus/exposuede57.htm>. Acesso em: 05 out. 2012.

DOLTO, Françoise. Les Chemins de l'Éducation. Paris: Gallimard, 1994.

FERREIRA, Aurélio Buarque Holanda. Novo Dicionário Aurélio da Língua Portuguesa. Rio de Janeiro: Editora Nova Fronteira, 1986.

FREUD, Sigmund. Algumas Reflexões Sobre a Psicologia do Escolar. In: FREUD, Sigmund. Edição Standard Brasileira das Obras Psicológicas Completas de Sigmund Freud. Rio de Janeiro: Imago Editora, 1990 [1914]. Volume 13. 
GOMES, Candido Alberto. A Escola de Qualidade Para Todos: abrindo as camadas de cebola. Avaliação de Políticas Publicas Educacionais, Rio de Janeiro, n. 13, p. 281-306, jul./set. 2005.

KLEIN, Ruben; FONTANIVE, Nilma Santos. Relatório dos Fatores Associados ao Desempenho dos Alunos da Fundação Bradesco 2009. Rio de Janeiro: Fundação Cesgranrio, 2010.

LACAN, Jacques. Fonction et Champ de la Parole et du Langage en Psychanalyse. In: LACAN, Jacques. Écrits I. Paris. Éditions du Seuil, 1966 [1953].

LAJONQUIÈRE, Leandro de. Dos Erros e em Especial Daquele de Renunciar à Educação. Estilos da Clínica, São Paulo, Universidade de São Paulo, v. 2, n. 2, p. 27-43, 1997.

LAJONQUIÈRE, Leandro de. Infância e Ilusão (Psico)Pedagógica. Petrópolis: Vozes, 1999.

LAJONQUIÈRE, Leandro de. Figuras do Infantil. Petrópolis: Vozes, 2010.

LAJONQUIÈRE, Leandro de. A Mestria da Palavra e a Formação de Professores. Educação \& Realidade, Porto Alegre, v. 36, n. 3, p. 849-865, set./dez. 2011.

PATTO, Maria Helena Souza. A Produção do Fracasso Escolar. São Paulo: T. A. Queiroz, 1990.

POMMIER, Gerard. Comment les Neurosciences Démontrent la Psychanalyse. Paris : Flammarion, 2004.

SCARTEZINI, Raquel Antunes; VIANA, Terezinha de Camargo. O Efeito-Professor e sua Transmissibilidade. In: COLÓQUIO DO LEPSI IP/FE-USP, O Declínio dos Saberes e o Mercado do gozo, 8., 2010, São Paulo. Anais eletrônicos... Disponível em: <http://www.proceedings.scielo.br/scielo.php?script=sci_arttext\&pi d=MSC0000000032010000100058\&lng=pt\&nrm=abn $>$. Acesso em: 01 out. 2012.

SOARES, Tufi Machado. Influência do Professor e do Ambiente em Sala de Aula sobre a Proficiência Alcançada pelos Alunos Avaliados no SIMAVE-2002. Estudos em Avaliação Educacional, São Paulo, n. 28, p. 103-124, jul./dez. 2003.

Leandro de Lajonquière é doutor pela Universidade Estadual de Campinas (Unicamp) (1992), Livre-docência na Universidade de São Paulo (USP) (1999) e Diploma de HDR junto à Université Paris 8 (2011). Professor Titular da Universidade de São Paulo, São Paulo/SP, desde 2005. Obteve a titulação acadêmica francesa Professeur des universités em 2012. Membro fundador do laboratório LEPSI da USP e membro do CERSE EA 965 - UCBN - França. Psicanalista, membro de Analyse Freudienne (Paris).

E-mail: ldelajon@usp.br 